\title{
Intermédialités
}

Histoire et théorie des arts, des lettres et des techniques

Intermediality

History and Theory of the Arts, Literature and Technologies

\section{Diagramming Duration : Bergsonian Multiplicity and Chaos Theory}

\section{Paul Harris}

Numéro 3, printemps 2004

Devenir-Bergson

Becoming-Bergson

URI : https://id.erudit.org/iderudit/1005470ar

DOI : https://doi.org/10.7202/1005470ar

Aller au sommaire du numéro

Éditeur(s)

Centre de recherche sur l'intermédialité

ISSN

1705-8546 (imprimé)

1920-3136 (numérique)

Découvrir la revue

Citer cet article

Harris, P. (2004). Diagramming Duration : Bergsonian Multiplicity and Chaos

Theory. Intermédialités / Intermediality, (3), 97-117.

https://doi.org/10.7202/1005470ar
Résumé de l'article

Cet article retrace les efforts menés par Bergson dans son «Introduction à la métaphysique ", afin de découvrir une façon de représenter, par le langage, sa notion de " durée réelle ", entendue comme une multiplicité continue. L'auteur suggère que les images graphiques générées par ordinateur afin de représenter la théorie du chaos en offrent la possibilité, avant de développer les conséquences conceptuelles et théoriques que cette corrélation entraîne. 


\title{
Diagramming Duration: Bergsonian Multiplicity and Chaos Theory
}

\author{
PAUL HARRIS
}

\section{FINDING WORDS FOR MULTIPLICITY}

From the very outset, Bergson's oeuvre is shaped by the problem of how to express his philosophical concepts in language. Bergson begins the "Author's Preface" to his first book, Durée et simultanéité, by conceding that "Nous nous exprimons nécessairement par des mots, et nous pensons le plus souvent dans l'espace." Both language and space habitually tend toward "une traduction illégitime de l'inétendu en étendue, de la qualité en quantité," thereby contributing to fundamental epistemological errors and occluding the true nature of duration. Even as he developed a distinctive style and vocabulary of his own, Bergson repeatedly confronted the difficulty that the very means to describe or elucidate his metaphysics seem to run contrary to or betray its essential tenets. In retrospect, one may see the wide disciplinary sweep of Bergson's writings as in part a reaction to this problem; it is as if he pursued an ongoing search for the linguistic and conceptual ground most appropriate for expressing his philosophical system. Today, thinking through Bergson's work in the light of contemporary medialities, we may add an additional, retrospective line of speculation. This essay argues that scientific techniques enabled by digital media provide a means of resolving specific difficulties Bergson encountered in trying to translate temporal concepts into language.

What was it that Bergson found so hard to put into words? In a 1915 letter, Bergson stated that "the core of [his] doctrine" ("le centre même de ma doctrine")

1. Henri Bergson, "Avant-propos," Essais, Paris, Presses universitaires de France, 1983 [1889], p. VII.

2. Henri Bergson, "Avant-propos," p. XIII. 
rests with "the intuition of duration" ("l'intuition de la durée"): "La représentation d'une multiplicité de 'pénétration réciproque,' toute différente de la multiplicité numérique-la représentation d'une durée hétérogène, qualitative, créatriceest le point d'où je suis parti et où je suis constamment revenu."3 If multiplicity is the central Bergsonian concept, and language among the foremost methodological challenges he faced, then clearly his attempts to find the proper formulation for multiplicity mark decisive moments in his work. The conundrum of how to express an idea of time without capturing time, without rendering it static and hence no longer temporal, is of course a general one. But if we were to state Bergson's particular dilemma, we might use his own terms and say that the very act of representing multiplicity in words presents a potential trap, that to do so is to transpose a virtual concept into an actualized symbolic entity. And so when he does write about multiplicity, Bergson tends to proffer several alternate formulations of the concept, only to insist on their inadequacy. At times, his train of thought becomes uncharacteristically snarled, because it cannot find the proper outlet.

The short essay "Introduction à la métaphysique," originally published in 1903, provides a particularly cogent instance of Bergson trying to find the right words to convey his idea that duration is a certain form of multiplicity. This text succinctly summarizes the philosophy developed in Durée et simultanéité and Matière et mémoire. And because it purported to provide a compressed, accessible introduction to his thought and method, this work reveals the crux of Bergson's struggle with language: on the one hand, he demonstrates his power as a philosophical writer, which rests largely in his ability to convey metaphysical concepts by creating easily comprehensible metaphors or analogies; on the other hand though, each explanatory figure he uses fails in some way, forcing him ultimately to locate the true nature of duration just beyond the reach of language. It is in the very gaps where these shortcomings reside that our retrospective reading of Bergson and medialities begins its work.

We can already anticipate Bergson's predicament when he proclaims at the outset that metaphysics is to be "la science qui prétend se passer de symboles."

3. Henri Bergson, "Bergson à Harald Höffding," [15 mars 1915], dans Mélanges, André Robinet (ed.), Paris, Presses universitaires de France, 1972, p. 1148.

4. Henri Bergson, "Introduction à la métaphysique" [1903], La pensée et le mouvant: Essais et conférences, Paris, Librairie Félix Alcan, 1939 [1934], p. 206. Henceforth, references to this text will be indicated by the initials "IM," followed by the page number, and placed between parentheses in the body of the text. 
Metaphysics must struggle to adhere to an asignifying stream of thought, which does not differentiate its proper object (duration as continuous multiplicity) by projecting it onto discrete symbols. Thus while science re-presents its objects of study in mathematical terms and spatial models, Bergson argues, metaphysics will be founded on an immediate apprehension of its objects of thought from within. It will generate intuitive knowledge based on a "sympathy" with its object rather than "analysis" of the whole in terms of its parts. Yet of course metaphysics cannot be simply left altogether outside language, for some symbolic form is necessary to communicate the idea, to induce thought to stretch itself to an intuition of duration. Thus when Bergson identifies the means by which metaphysics expresses itself, he calls for a specific form that the concept must take if metaphysics is to be disclosed without losing its essential character.

Certes les concepts sont indispensables [à la métaphysique], car toutes les autres sciences travaillent le plus ordinairement sur des concepts, et la métaphysique ne saurait se passer des autres sciences. Mais elle n'est proprement elle-même que lorsqu'elle dépasse le concept, ou du moins lorsqu'elle s'affranchit des concepts raides et tout faits pour créer des concepts bien différents de ceux que nous manions d'habitude, je veux dire des représentations souples, mobiles, presque fluides, toujours prêtes à se mouler sur les formes fuyantes de l'intuition. (IM, p. 213-214, my emphasis)

The passage is indicative of Bergson's continual search for conceptual terms whose texture, we might say, would correspond to the quality of duration. It also enables us to shift the grounds of the problem: it is not so much that Bergson wished to avoid contaminating metaphysics by putting it into words per se, but that he found the symbolic tools available in all fields lacking the right texture or character. The specific "rigid concepts" he alludes to here issue from the rival sciences he seeks to resist, especially Spencer's mechanism.

\section{CHAOS ENTERS THE PICTURE}

I wish to explore a rather simple-sounding thesis: that computer-generated diagrams used in chaos theory provide symbolic tools adequate for expressing specific aspects of the concepts Bergson struggles to articulate in his writing. The role of mediality in the development of chaos theory is well-known. Part of the popular chaos mythos is that while the mathematical seeds of chaos theory were planted by Poincaré and others in the period Bergson was writing, it took the calculating power and graphic displays of the computer to bring the science to full fruition. Likewise, Bergson's tangled ruminations on multiplicity 
seem to find visual representation in graphic representations of chaos models. On a different level, other types of resonances between Bergson and chaos theory present themselves for analysis. Terms which overlap the two discoursessuch as "virtual" and "multiplicity" - present opportunities for fuller comparative discussion. Such discussion, while sensitive to the different meanings attached to common terms, also show the conceptual convergence between Bergson's philosophy and chaos science.

Still, we must ask, why would chaos theory prove philosophically relevant to Bergson's theory of duration? Broadly speaking, chaos theory is a form of dynamical systems theory, a science concerned with how systems evolve in time, usually according to a rule. Chaos theory models systems behave, well, chaotically. As is well known by now, "chaotically" usually means not completely random or all-over-the-place, but a combination of local unpredictability and some form of global order. It used to be that if a system did not behave according to the laws of classical dynamics (where position and momentum of the variables yielded a picture of the system's evolution), knowledge of it was limited to being statistical. The evolution of a system driven by "chaos dynamics" lies halfway between the stable, predictable trajectories of a classical dynamical system and the random behavior of a system like molecules colliding in a gas. One scenario of how a dynamical system evolves is that it starts out from an initial condition, follows a trajectory within a certain region of its possible behaviors, comes to a fork in its road (a bifurcation point), and, depending on very slight differences, will follow one path or another, and go roaming around the next relatively well defined region for a while, until the next fork comes along. This crudely rendered account conveys some of the qualities that make a dynamical system's evolution a good intuitive fit for Bergson's idea of duration as a multiplicity. This general likeness has been noticed by mathematicians and scientists as well. Rudy Rucker, for instance, imagines "life as a fractal in Hilbert Space."5

What are some more particular ways in which chaos theory has yielded philosophical interest? As is always the case, to answer this question requires two steps: the mathematical/scientific materials must be first understood on their own terms and treated accurately, before subsequently being interpreted from a philosophical standpoint. This distinction has proved rather tricky in the

5. Rudy Rucker, Mind Tools: The Five Levels of Mathematical Reality, Boston, Houghton Mifflin, 1987, p 178. 
case of chaos theory though for a number of reasons. From the onset of its popularity in the 1980's, chaos theory exerted a strong aesthetic and philosophical appeal, in large part because of the very nature of what I will refer to as 'chaos diagrams' - the graphic representations of mathematical models of chaos. Fractal art exhibitions, fractal calendars, software programs all brought art and science together in some way. Simultaneously, scientists instrumental in popularizing chaos theory discussed its philosophical and historical implications, sometimes rather freely. For some, the fact that science was studying nonlinear systems and chaos held out the promise that western science was exploring realms and patterns it had hitherto ignored or excluded. For others, it was as if the interest of science were undergoing a philosophical inflection. As we will see, chaos theory has raised important philosophical issues in new ways. Moreover, two of these issues are crucial to Bergson's concept of multiplicity: the problem of free will versus determinism, and the interactions between parts in a whole.

\section{DIAGRAMS: MATHEMATICS, SCIENCE AND PHILOSOPHY}

We can find in chaos diagrams a sort of double coding: on the one hand, visual displays which often cannot be immediately correlated with a referent or whose 'real meaning' is not easily understood; on the other hand, visual displays which represent mathematics as a process of material construction rather than rarefied manipulation of transparent symbols. Taken together these characteristics enable chaos diagrams to be used as heuristic devices which 'embody' some set of relations, without regard to actual content. When I propose specific chaos diagrams as resolutions to dilemmas which arise in Bergson's philosophical discourse, the diagrams serve as precisely this kind of conceptual algorithm; they provide a means of condensing some complex set of relationships into an abstract configuration.

In other words, as diagrams begin to function as philosophical signs, they become energized with a certain potential. Their power rests in the range of their potential uses or meanings; they designate some set of relations which could be obtained in any number of specific contexts. This way of conceptualizing and mobilizing diagrams is an important part of Deleuze's philosophical method, in that one of his main interests is to disclose homologous patterns and dynamics which underlie processes in disparate domains of the social and physical worlds. Deleuze thus deploys the term diagram in an abstract sense. For Deleuze, a "diagram" is not a static schema or a sketch designed to map the internal relations in a system or whole, but a compressed expression of an insight or 
intuition that has not yet been given explicit form. In other words, a diagram enfolds a set of relations that must be unfolded in order to be subject to interpretation. "Un diagramme en effet n'a pas de substance ni de forme, et pas de contenu ni d'expression." The diagram is not really a "sign," in the sense that it does not belong to a pre-existing sign system; it is not an "object" either, since it has no physical reality. The diagram therefore expresses virtual relations; it operates on a conceptual rather than representational plane. ${ }^{7}$

In the process of "diagramming duration," I am not trying to collapse all differences between Bergson's metaphysical writing and the diagrams of chaos theory, but to induce them to approach a common conceptual surface asymptotically. It is as if the philosophical concept of duration were inflected toward the mathematical sign, and conversely, the chaos diagrams were hearkening back to the chaos that they arrest into mathematical and graphic representations. If we follow Massumi's assertions that a diagram designates an encounter, a set of relations between entities, and that a diagram does not crystallize a stable idea, for it persists in "a process of becoming," then diagramming duration itself becomes a self-similar procedure where duration, whose very nature is becoming, gets expressed with conceptual tools that themselves embody becoming.

\section{DIAGRAMMING DURATION}

In order to show how chaos diagrams give explicit form to the elusive metaphysical notion of duration, I will examine at length a section of "Introduction à la métaphysique" where Bergson proposes one explanatory metaphor for duration after another, only to find them inadequate, if not deceptive. In essence, we find that Bergson lacks any notion of "space" or spatial metaphors which would accommodate the definitive characteristics of his concept of multiplicity. The chief impasse lies in that fact that qualitative or continuous multiplicity entails "reciprocal penetration," a tangled weave of sorts, and Bergson could not find a visual or spatial analogue because he equated space in general with the Euclidean space of common sense. Quite simply, the main reason that chaos diagrams serve as such effective heuristic supplements for Bergson's

6. Gilles Deleuze, Félix Guattari, Capitalisme et schizophrénie. Mille plateaux, Paris, Éditions de Minuit, coll. «Critique», 1980, p. 176.

7. Gilles Deleuze, Félix Guattari, Mille plateaux, p. 176-177.

8. Brian Massumi, A User's Guide to Capitalism and Schizophrenia, Cambridge, Massachusetts, MIT Press, 1992, p. 14. 
metaphors for multiplicity is that they are constructed in fractional dimensional spaces where successive magnifications reveal "reciprocal penetration" across different scales. As I proceed now to match one Bergsonian metaphor after another to a particular chaos diagram, the interpretation will no doubt seem rather mechanistic, and my treatment of chaos diagrams rather superficial. But this is only an initial examination of ways to map a conceptual space common to Bergson and chaos theory; the discussion turns from a plane of representation (verbal metaphors matched to visual diagrams) to conceptualization (the relational structure underlying the discourses). One reason to let the discussion unfold this way is that it enacts the process most frequently followed in interdisciplinary thinking: to move from an initial insight of some general analogy between two objects of study to a fuller discussion of where the analogy can take us, where the differences lie, etc.

What immediately strikes one about "Introduction à la métaphysique" is the simplicity of its language and the clarity of its exposition. At a time when a premium is placed on expressing technical concepts in non-technical language, Bergson's style could be taken as a shining example of how conceptual exposition may meet with poetic style without suffering from excess verbiage. Bergson seeks in this text to find words for both the qualitative feeling and conceptual properties of duration. Having defined metaphysics as the "science qui prétend se passer de symboles," Bergson explains how it is that metaphysics can work as a form of immediate or immanent knowledge. He takes as his first subject the stream of conscious thought, since "il y a une réalité au moins que nous saisissons tous du dedans, par intuition et non par simple analyse. C'est notre propre personne dans son écoulement à travers le temps." (IM, p. 206) Bergson marks how when viewed from the outside, in retrospect, this stream of the "inner life" breaks into discrete thoughts which he says "crust" themselves into "objects" or "sharply cut crystals." Yet intuition also apprehends underneath this "frozen surface" a "continuous flux" proper to duration. ${ }^{9}$ How can

9. "Quand je promène sur ma personne, supposée inactive, le regard intérieur de ma conscience, j’aperçois d'abord, ainsi qu'une croûte solidifiée à la surface, toutes les perceptions qui lui arrivent du monde matériel. Ces perceptions sont nettes, distinctes, juxtaposées, ou juxtaposables les unes aux autres; elles cherchent à se grouper en objets. J'aperçois ensuite des souvenirs plus ou moins adhérents à ces perceptions et qui servent à les interpréter [...] C'est au-dessous de ces cristaux bien découpés et de cette congélation superficielle, une continuité d'écoulement qui n'est comparable à rien de ce que j'ai vu s'écouler." (IM, p. 206-207) 
this interior continuous flux be expressed in some symbolic form, without becoming discrete and static in the process?

\section{I THE BALL OF THREAD}

Bergson's solution is to find the fitting metaphor for duration. The first explanatory simile comes when he observes that this inner life may be compared to the unrolling of a coil (déroulement d'un rouleau), "car il n'y a pas d'être vivant qui ne se sente arriver peu à peu au bout de son rôle.” (IM, p. 208) But this unidirectional linear image fails to account for the cumulative character of the inner life, for memory; thus the inner life is "tout aussi bien un enroulement continuel, comme celui d'un fil sur une pelote, car notre passé nous suit, il se

104 grossit sans cesse du présent qu'il ramasse sur sa route." (IM, p. 208) What is most intriguing here is that even as he uses images of linear trajectories to describe duration, Bergson is exploding or at least exceeding the models built on trajectories and the classical dynamics that these models express. For when Bergson tries to imagine the continuous and cumulative aspects of duration in terms of thread and a ball, he literally wants it both ways: he needs the thread unwinding off the coil to figure human finitude, and the ball winding up, growing bigger, as the thread of the present accumulates more and more memory.

It seems that Bergson's focus on the qualitative register of temporality precludes his taking a more careful interest in the consistency of his spatial metaphors. Here Bergson seems simply to pass over the fact that his two images collapse together two different orders of spatial magnitude: the two-dimensional thread and three-dimensional ball. Instead of taking the ball and running with it, he drops the metaphor - as if he senses the incommensurability between the trajectories paradigm and duration. Bergson rejects the threads images because: “[elles] évoquent la représentation de lignes ou de surfaces dont les parties sont homogènes entre elles et superposables les unes aux autres" (IM, p. 208), whereas duration is heterogeneous and composed of "reciprocally penetrating" parts.

But it is possible to imagine the images of uncoiling thread and thread rolling up onto a ball within a single representation, for this is what characterizes the chaos diagram known as a Lorentz attractor (fig. 1). This image has become a familiar trademark of computer graphics: two disk-like configurations that resemble the grooves on a record, intertwined by trajectories that cross over from one to the other. The rotational motions run in different directions on each one, providing an apt-if rather literal - analogy for Bergson's "unrolling" and "rolling up" threads. But the Lorentz attractor works as a fitting figure for 


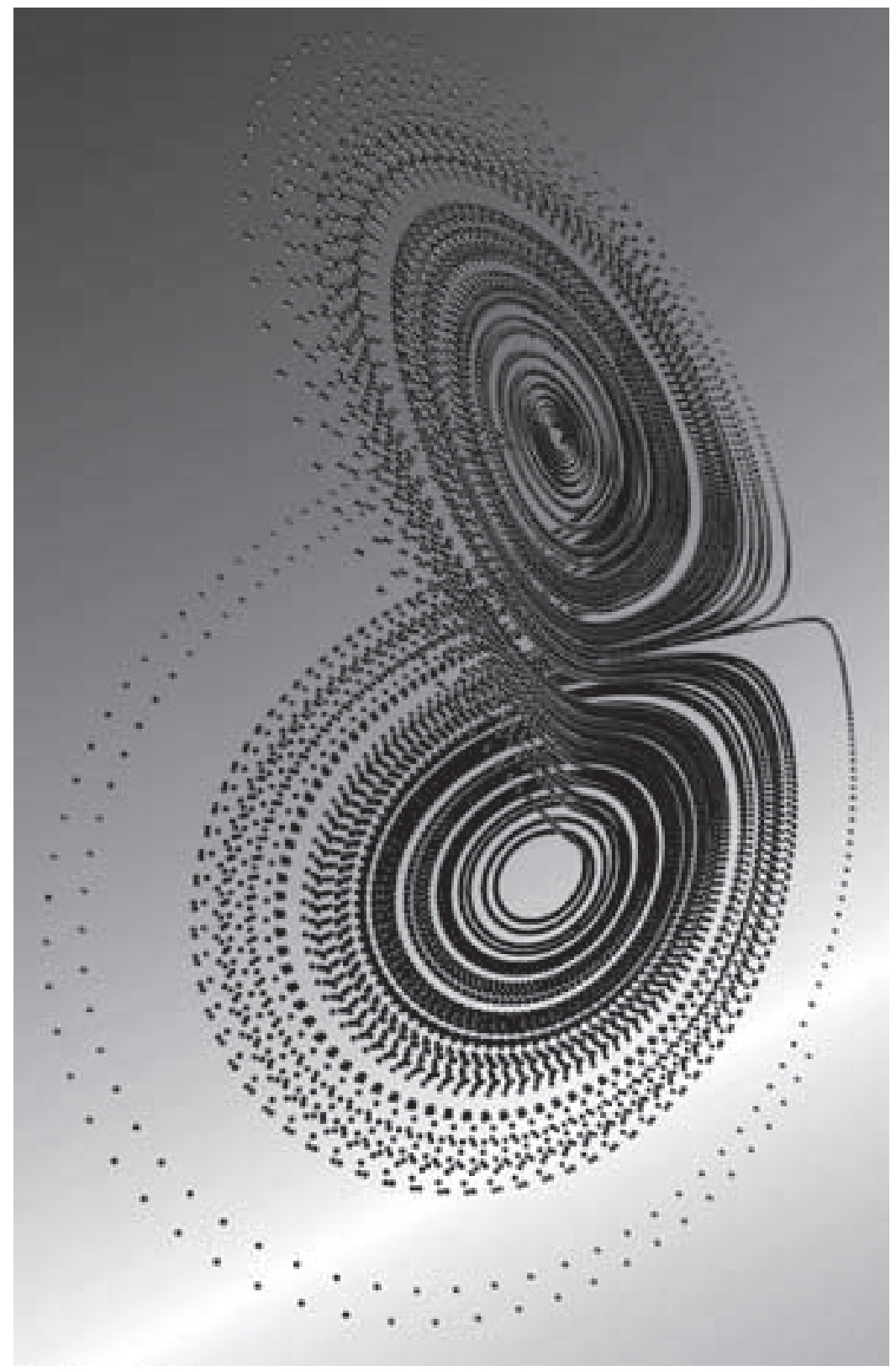

Fig. 1. The Lorenz attractor. 
Bergson's two thread metaphors at a more conceptual level as well. Bergson employs the image of an unrolling thread as a figure for the span of a person's inner life, a time-line distinguished in Bergson's thought by its unpredictability, its openness to choice. This thread of Bergson's thought finds its equivalent in the Lorentz attractor in the paths of trajectories, which are locally unpredictable and never overlap with one another. Bergson's image of the rolling up of the thread onto a ball, on the other hand, stands for the qualitative identity that accumulates in a person's life, the constraint that memory places on the unfolding present of duration. This thread is expressed on the Lorentz attractor as the forming of the composite figure, the attractor to whose general outline the trajectories adhere on a global scale. The attractor evolves as an increasingly enfolded mesh of paths that never cross, because they embed themselves in a fractional-dimension figure.

Thus while Bergson discarded the threads and ball figure because it involved a "homogeneous" space in which lines and surfaces were "superposable on one another," the enmeshed tangle of the attractor forms a mottled texture of irreducible heterogeneity - there is no way to contract the attractor. It is a heuristic convenience that the fractional dimension of this attractor is between two and three dimensions, for it provides a space that we could imagine as the result of collapsing the two-dimensional threads and the three-dimensional ball. In fact, Mandelbrot uses a ball of thread as an example of how the dimensionality of an object depends on point of view and scale of measure, and then proceeds from there to introduce the idea of fractional dimensions. ${ }^{10}$

\subsection{THE COLOR SPECTRUM}

Returning now to the passage from "Introduction à la métaphysique," Bergson moves on to his next simile: struggling to find a metaphor for the fact that the continuous flow of duration continually traverses qualitatively heterogeneous moments, Bergson compares duration to "un spectre aux mille nuances, avec des dégradations insensibles qui font qu'on passe d'une nuance à l'autre." (IM, p. 208) The inner life would then be imagined as "un courant de sentiment qui traverserait le spectre en se teignant tour à tour de chacune de ses nuances, [qui] éprouverait des changements graduels dont chacun annoncerait le suivant

10. Benoit Mandelbrot, The Fractal Geometry of Nature, New York, Freeman Press, 1983 , p. 17 . 


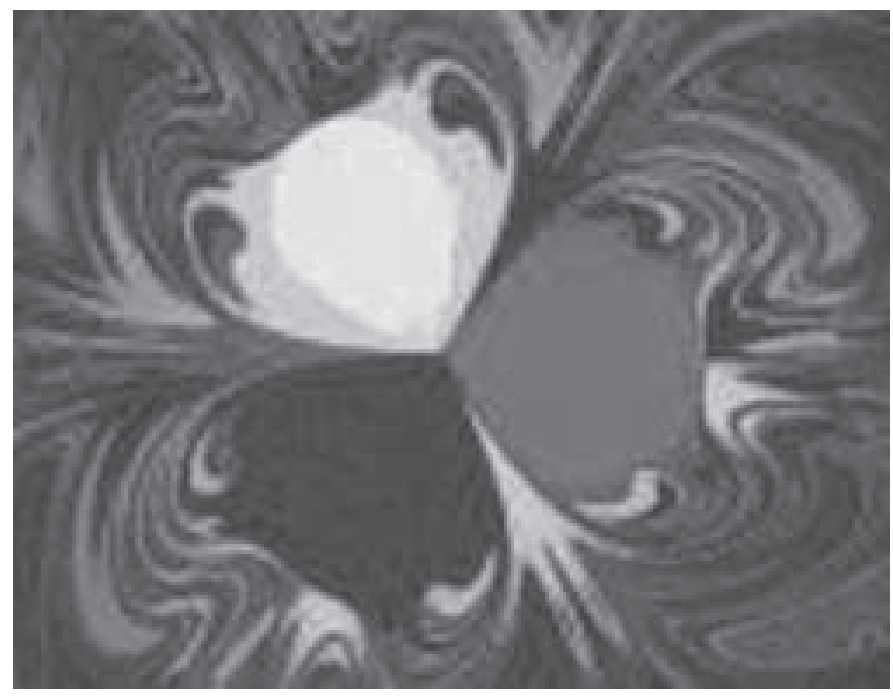

Fig. 2. Fractal basin boudary.

et résumerait en lui ceux qui le précèdent." (IM, p. 208-209) Bergson’s simile is particularly, almost poetically effective because it not only expresses the smooth or continuous spatial motion of duration as it passes through qualitatively different "states," but also captures something essential about its texture - the "tints" fittingly express the affective dimension of the inner life, as when we speak of the "coloring" of an event or experience.

However, for Bergson this metaphor is also dangerously misleading. Bergson must make a distinction between the color spectrum and duration, because "les nuances successives du spectre resteront [...] toujours extérieures les unes aux autres. Elle se juxtaposent. Elles occupent de l'espace," while “[la] durée pure exclut toute idée de juxtaposition, d'extériorité réciproque et d'étendue." (IM, p. 209) Here, Bergson again insists on a diametric opposition between time and space based on the assumption that space is necessarily a homogeneous, empty Euclidean plane or box. In order to make a metaphor of colored regions correspond to Bergson's stipulation that duration precludes any type of rigid spatial demarcation, one would need to imagine a color spectrum where colors do not succeed one another in a discrete sequence. This entails a mutual imbrication of colors in one another, a space where one color's presence does not simply exclude another's, where each seeming edge separating colors would reveal other colors embedded in the very division. 
Such a spectrum of colors appears in images of the boundaries of fractal basins of attraction (fig. 2). The usual color rendering of a fractal basin boundary shows something that resembles a three-leaf (or four) clover shape, with different colors for each leaf. But the borders between different regions of color themselves fracture into a clover figure, where the "line" between two colors contains a new leaf composed of the other colors, whose edges in turn reveal more clover leaves. The points that lie on the borders between colored regions, called "boundary points," actually belong to all three regions or basins of attraction. Thus the discrete borders between colors are themselves not sharp lines of separation at all, yielding a figure that effaces the strict juxtapositions and boundaries that made Bergson reject the color-spectrum metaphor: the "reciprocal externality" of regions gives way to a spatial model where, in any one region of color, all the other colors or tints will be found enfolded into the fractal basin. The fractal basin boundary thus presents an analogy with a color spectrum where tints are not juxtaposed or external to one another, nor do they extend "in" space or occupy in a bounded manner.

\subsection{DRAWING THE LINE}

Returning again to the "Introduction à la métaphysique": after demonstrating the inadequacy of the spectrum metaphor, Bergson finds one final image to represent duration. With this image, his formulation comes intriguingly close to an explicit description of certain chaos diagrams. Bergson asks that we imagine "un élastique infiniment petit, contracté, si c'était possible, en un point mathématique. Tirons-le progressivement de manière à faire sortir du point une ligne qui ira toujours s'agrandissant." (IM, p. 209) Wary that the reader might associate the image of the lengthening line with the previous images of the unrolling thread, Bergson immediately directs us: "fixons notre attention, non pas sur la ligne en tant que ligne, mais sur l'action qui la trace." (IM, p. 209) This seemingly simple distinction invokes Bergson's crucial differentiation between movement itself, and the space that movement traverses. The "action" of the line being traced, the tracing itself, is a continuous, "indivisible" action; but if we think of it as a line, it becomes a stationary segment and thus can be broken into smaller "cuts." This distinction was the basis for Bergson's answer to Zeno's paradoxes, which are founded on the translation from continuous movement to discrete steps. Bergson concludes by stipulating that if we wish to correlate movement and duration, "dégageons-nous enfin de l'espace qui sous- 
tend le mouvement pour ne tenir compte que du mouvement lui-même, de l'acte de tension ou d'extension, enfin de la mobilité pure." (IM, p. 209)

Bergson's distinction between movement and its representation as a trajectory in space is immensely important in this context. Bergson's philosophical distinction may be understood in relation to the classical dynamical models of his day. The dominant model, first formulated by Lagrange in 1788, depicts motion not as a primary event but as an effect, a kind of epiphenomenon. This model derives motion from static representations of spatial and temporal position. Thus motion remains chained to the rate of change of position; in both a technical and figurative sense, motion is a derivative of position. When Bergson demands that we free motion from the space it occupies, he reverses this dependence of movement on position: he places motion prior to change of position, making it impossible to think of motion as a sequence of dimensionless points threaded together. However, in separating movement from its trajectory and position in space, Bergson also creates an internal fracture in his own metaphor: that is, the first term or tenor of the metaphor (the "contraction" of an "elastic body" [corps élastique] to "a mathematical point," and the "line" that extends out from that point) is separated from the metaphor's second term or vehicle: the movement is extracted from the space. Seeking to embody duration with a metaphor, he disembodies the metaphor by taking away its very ground.

Chaos diagrams are composed in a way that trace a way out of the dilemma in which Bergson's metaphors place him. First, chaos dynamics differs crucially from classical dynamics in that space no longer precedes movement in the same way. A chaotic motion or "orbit" does not occupy a fixed, box-like space; it rather outlines the space needed to hold it as it unfolds; it produces its own spatial form as it evolves. Deleuze and Guattari conceptualize this kind of diagramming in terms of "smooth space" (espace lisse). They stipulate that smooth space "se constitue par construction d'une ligne de dimension fractionnaire supérieure à 1 , d'une surface de dimension fractionnaire supérieure à 2." ${ }^{11}$ Because "l'espace lisse se définit [...] en ce qu'il n'a pas de dimension supplémentaire à ce qui le parcourt ou s'inscrit en lui [...], par exemple une ligne qui remplit en tant que telle un plan," smooth space involves situations where "l'espace lui-même et ce qui occupe l'espace tendent à s'identifier."

11. Gilles Deleuze, Félix Guattari, Mille plateaux, p. 6o9.

12. Gilles Deleuze, Félix Guattari, Mille plateaux, p. 609. 
Consider the Menger sponge and other figures of fractional dimension: can one say there is a space they fill up? No; it creates its own space as it takes its formspace and what occupies it are one and the same. Similarly, an orbit of a system in phase space is not a trajectory through a Euclidean box of length, width and depth; dimensions of phase space represent variables of the system, so an orbit does not represent a system's motion in space, but "a map of the changes in the system's behavior over repeated cycles." ${ }^{13}$

If Bergson's image is diagrammed using tools from chaos theory, it would unfold as follows. The body contracted to a point, from which a line extends out, becomes a tangled mesh, a spreading shape of constant volume that occupies more and more of a multi-dimensional phase space. What Bergson imagined as a linear trajectory "in" space (which he then had to extract from the space) gives way to a fractal-dimensional, shifting form that creates the space it occupies. Prigogine and Stengers's description of how to diagram the evolution of an unstable system redraws Bergson's image on a chaos graph very neatly:

Suppose that our knowledge of initial conditions permits us to localize a system in a small cell of the phase space. During its evolution, we shall see this initial cell twist and turn and, like an amoeba, send out "pseudopods" in all directions, spreading out in increasingly thinner and ever more twisted filaments until it finally invades the whole space. ${ }^{14}$

Here the contracted figure at the beginning traces out a distinctive shape from that initial point or cell, with a continuous motion that comes to be identified with the space itself. We should not simply imagine that the "dynamics" of duration are now given an easily accessible spatial representation, or that the diagram simply "re-presents" the dynamics. Prigogine and Stengers emphasize that the diagram does not provide a clear account of this type of motion, because "no sketch can do justice to the actual complexity of the situation." 15 Phase space allows one to contract a system's behavior onto a diagram, but the diagram remains an approximation.

13. Katherine N. Hayles, Chaos Bound: Orderly Disorder in Contemporary Literature and Science, Ithaca, New York, Cornell University Press, 1990, p. 148.

14. Ilya Prigogine, Isabelle Stengers, Order out of Chaos: Man's New Dialogue with Nature, New York, Bantam Books, 1984, p. 267.

15. Ily Prigogine, Isabelle Stengers, Order out of Chaos, p. 267. 


\subsection{CONTINUOUS MULTIPLICITY}

Picking up the passage from "Introduction à la métaphysique", Bergson drops the contracted point metaphor for duration because while it expresses the "movement simple par lequel la conscience passe d'une nuance à l'autre," (IM, p. 210) this simple movement depicted as a smooth line fails to express the heterogeneity of duration, its continual differing from itself. For Bergson, the insurmountable difficulty in finding the proper conceptual figure for duration is that no image can represent duration as both continuous with itself and differing from itself. Duration cannot be rendered in a single figure of language or thought because it "ressemble par certains côtés à l'unité d'un mouvement qui progresse, par d'autres à une multiplicité d'états qui s'étalent, et qu'aucune métaphore ne peut rendre un des deux aspects sans sacrifier l'autre." (IM, p. 209210) Bergson is thus left simply to contain the problem in a paradoxical-for him perhaps oxymoronic-formulation. The continuous "unity of advancing movement" and its irreducible "multiplicity" of content leave Bergson to posit that duration is a continuous multiplicity, even if he must admit that: "s'il y a une multiplicité $[\ldots]$, cette multiplicité ne ressemble à aucune autre." (IM, p. 214) Thus while Bergson maintains that duration is a consistent philosophical concept, in his rhetorical turnings duration is figured as a concept split into two seemingly contradictory components. The self's "inner life" as both "the unity of an advancing movement" ("unité d'un mouvement qui progresse") and "the multiplicity of expanding states" ("multiplicité d'états qui s'étalent") cannot be grasped in a single image; "aucune métaphore ne peut rendre un des deux aspects sans sacrifier l'autre." (IM, p. 209) Bergson recapitulates this dilemma once more with a note of resignation:

Conclurons-nous de là que la durée doit se définir par l'unité et la multiplicité tout à la fois? Mais, chose singulière, j'aurai beau manipuler les deux concepts, les doser, les combiner diversement ensemble, pratiquer sur eux les plus subtiles opérations de chimie mentale, je n'obtiendrai jamais rien qui ressemble à l'intuition simple que j’ai de la durée. (IM, p. 214)

\section{THE KNEAD FOR CHAOS}

We now bring the diagramming of duration to a close with a final set of connections between Bergson's metaphysics and chaos theory. The basic line of thought here runs as follows: fractal attractors may be mobilized as diagrams for duration because they exemplify and help conceptualize its structural princi- 
ples, the primary one of which is a double movement of horizontal unfolding and vertical recoil or rotation. On the one hand, the horizontal movement is figured on the fractal attractor by its bundle of trajectories, which are governed by a local unpredictability or "sensitive to dependence to initial conditions." On the other hand, the vertical recoil is figured by the convergence of trajectories onto the attractor, which confines trajectories within a certain region of the phase space by embedding them in a pastry-like texture.

Here we may recall the seminal passage from Matière et mémoire, where Bergson identifies a double movement of duration.

La mémoire intégrale répond à l'appel d'un état présent par deux mouvements simultanés, l'un de translation, par lequel elle se porte toute entière au-devant de l'expérience et se contracte ainsi plus ou moins, sans se diviser, en vue de l'action, l'autre de rotation sur elle-même, par lequel elle s'oriente vers la situation du moment pour lui présenter la face la plus utile. ${ }^{16}$

At the formative level of duration, there are two "simultaneous movements" which weave together somehow without ever being superposable or homogeneous strands. These two movements traverse sides of what becomes a fold. A similar account is found in L'évolution créatrice. Bergson evokes the experience of

une durée où le passé, toujours en marche, se grossit sans cesse d'un présent absolument nouveau. Mais, en même temps, nous sentons se tendre, jusqu'à sa limite extrême, le ressort de notre volonté. Il faut que, par une contraction violente de notre personnalité sur elle-même, nous ramassions notre passé qui se dérobe, pour le pousser, compact et indivisé, dans un présent qu'il créera en s'y introduisant. $^{17}$

Here, what in Matière et mémoire was the "translation" that contracts the past into the present becomes in L'évolution créatrice a "swelling" of past into present. The earlier notion of the second movement as a "rotation upon itself" is elaborated as a "recoil upon itself," a movement that "gathers up" the past and "thrusts" it into the present. The rather remarkable passage from L'évolution créatrice contains the internal fissure that is embedded in Bergson's duration.

16. Henri Bergson, Matière et mémoire. Essai sur la relation du corps à l'esprit, Paris, Presses universitaires de France, coll. "Quadrige», 1985 [1896], p. 188.

17. Henri Bergson, L'évolution créatrice, Paris, Presses universitaires de France, coll. «Quadrige», 1986 [1907], p. 201. 
The first phrase transposes the discrete (particulate) succession past-presentfuture into a continuous (wave-like) movement, where the present unfolds from within the past as a "swelling." The past/present relation interior to this movement is then, in a second step, refigured as a complex folding: a backlooping gesture, a "recoil on itself," that "gather[s] up" the past, and folds it into the present. Yet it would be more accurate to say that the folding itself produces the present, for that present is projected simultaneously as something emergent just beyond Bergson's words ("a present it will create") and as a kind of gap preexisting the description (a slot there where the enfolded past enters).

Together, these two features compose the definitive trope of chaos. In an essay published in Scientific American that helped popularize chaos, members of the Santa Cruz Dynamical Systems Collective describe this metaphor succinctly:

The key to understanding chaotic behavior lies in understanding a simple stretching and folding operation, which takes place in the state space. Exponential divergence is a local feature: because attractors have finite size, two orbits on a chaotic attractor cannot diverge exponentially forever. Consequently, the attractor must fold over itself. [...] The process of stretching and folding happens repeatedly, creating folds within folds ad infinitum. A chaotic attractor is, in other words, a fractal: an object that reveals more detail as it is increasingly magnified. ${ }^{18}$

The authors compare the stretch and fold metaphor to rolling out and kneading dough. This operation is common to many chaotic models such as the baker transformation or Smale's horseshoe: a topological representation is flattened out, squeezed into a different shape, then folded over itself. A chaotic or fractal attractor, then, provides a spatial diagram of the definitive features of duration. The conceptual link between duration as continuous multiplicity and fractals finds its mathematical analogue expression in the fact that Riemann's continuous multiplicities are a class of fractals. ${ }^{19}$

The aesthetic appeal of fractals and other chaos diagrams has made it easy to think of them as static pictures or patterns, and indeed most of us have seen these images as glossy photos in books or calendars or on screen savers. However, the fixed nature of these representations of chaos diagrams cloaks the fact that graphic representations of chaos diagrams are arbitrarily halted snapshots of

18. James P. Crutchfield, J. Doyne Farmer, Norman H. Packard, Robert S. Shaw, "Chaos," Scientific American, vol. 255, no. 6, December 1986, p. 51.

19. Benoit Mandelbrot, The Fractal Geometry of Nature, p. 420. 
iterative mathematical operations. The explicit shape of fractals implicitly point to further potential versions of themselves and mark limits the states of a system will approach; they are perceivable signs of a conceptual or potential configuration. In this way, they bear a limited resemblance to the metaphors for duration that Bergson employs: just as Bergson's metaphors must be exceeded in order to point to a concept beyond their reach or range of reference, fractals should be interpreted as signposts - indices in Peircean terms - rather than complete re-presentations. And because fractals retain a virtual persistence beyond the actual graphic representations that diagrams them on screens or paper, we could say that, as Massumi puts it, "the fractal attractor is the virtual. No actuality can effectively contract all of the fractal attractor's states into its bifurcations, or overlap with it entirely." ${ }^{20}$

An apt formulation of the matter would be that chaos diagrams are actual representations of virtual multiplicities. On the one hand, chaos diagrams are inscripted representations on an "actual" plane, which give visual expression to mathematical operations. On the other hand, these inscriptions are "virtual" in a complex sense. Because they are fractional dimensional objects, they fill space but have no volume (here I put the matter in terms referring to attractors between two and three dimensions); they therefore are diagrams of a process which could continue indefinitely. Furthermore, a chaotic attractor diagrams the limit toward which a set of initial points will tend; it can mark not the state of a system but the shape it would take. From a conceptual perspective, it is only fitting that chaos diagrams occupy a cusp where philosophy and science intersect. Perhaps the more (im)pertinent way to put it is that chaos diagrams turn the neat line between philosophy and science into one of those fractal basin boundaries, where points along the boundary reveal on closer scrutiny a richly tangled texture, where points to one side of the line turn out to belong to a region on the other side.

In this sense, the fractal maps onto the discussion of Bergson's descriptions of how the past gathers itself and folds into the present, that is, this folding cannot be reduced to a single heuristic metaphor or image, but must be figured as a process of continual remixture and redistribution. The fractal as actual object, we might say, has a presence in the present only as a virtual fissuring. Apprehended this way, the fractal functions not as an ideal object outside thought, but a diagram that filters thought into a mobile form. The fractal enacts or even 
embodies, stands in for, a fundamental duplicity which lurks at the very heart of "time" as a conceptual entity.

This split then becomes a source of difference and therefore a virtual ground for time. Deleuze identifies the split "itself" as "la perpétuelle foundation du temps, le temps non-chronologique, Cronos et non pas Chronos." ${ }^{21}$ Displacing Bergson's metaphysical emphasis on the continuous flow of time, Deleuze offers something like a poststructuralist speculative ontology here: rather than deconstructing a unified category, he posits a division as an internal structural principle. And so while he posits time as a meta-physical substrate, a definitive condition of our existence, Deleuze does not revert to metaphysics in any traditional sense. Time is not an exterior essence, but the modus operandi of the brain, "l'intériorité dans laquelle nous sommes."22 Yet there is something left over: we have spoken all along of the irreducibly continuous movement of duration, but now arrive at an operation that "extract $[s]$ non-chronological time." How can this be accommodated within our diagram for the conceptual space of metaphysics? What set of spatial relations can express an operation where one extracts something from the foundation of an interiority, without placing the interiority in a space external to it? If we diagram the problem in the spatial language of chaos, it is as if we place the fractal attractor of duration in a higher dimension - we take its double-movement and fix it as a shape in a containing space. But Deleuze maintains that the sheet of transformation defines a "transverse continuity" within an interiority.

Here, in a strictly metaphorical sense, we may borrow one more figure from chaos theory to diagram the form this metaphysical knowledge takes in our topological cerebral space. The Poincaré surface-of-section is a method used to study the properties of an attractor (fig. 3). Because the attractor is a thickly braided, impossibly entangled weave of trajectories, one cannot ever have an "objective" view of it. Instead, the Poincaré surface-of-section extracts a pattern by cutting a perpendicular slice of the attractor, producing a set of points that represent where the attractor passes through the plane. This set of points allows certain qualitative assessments to be made about the attractor, but does not yield any predictive or quantitative results. The heuristic power of the figure in this context lies in the fact that the surface-of-section is a lower-

21. Gilles Deleuze, L’image-temps, Paris, Éditions de Minuit, coll. «Critique», 1985, p. 109.

22. Gilles Deleuze, L'image-temps, p. 110. 


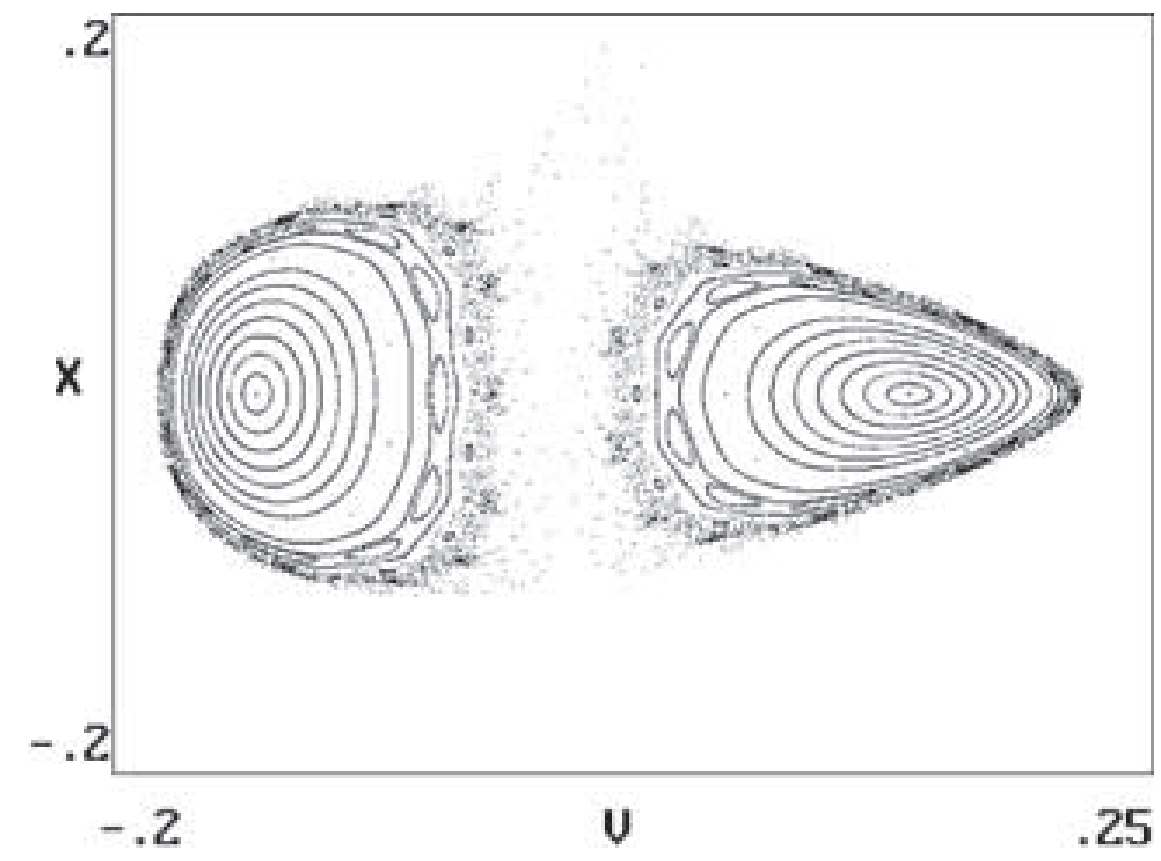

Fig. 3. The Poincaré section.

dimensional view, a procedure performed immanent to the whole; yet its pattern allows qualitative inferences and distinctions to be made about the nature of the system's behavior. This image of thought precludes the fixity of the concept, its exteriority to the object of its discourse. Instead, it is like a route through smooth space, where the route maps out its own space by proceeding.

\section{DIGITIZING DURATION}

In exploring relations between Bergson's work and mediality here, I hope that I have shown the heuristic richness of chaos diagrams as metaphors for time and thought. If Bergsonian metaphysics sought to map out something close to a metalanguage of thought, Deleuze's reformulation through the conceptual filter of chaos locates the metaphysical traversal of thought in an immanent position in relation to itself. If Bergson often spoke of the need for thought to double back on itself, or descend into its own depths, the trope shifts here to that of cutting across, of taking a transverse cut or section, and examining the 
topology or pattern of the thought. If we began by considering duration as the territory, for which fractal attractors became the map, then what got onto the map from the territory is the structure of duration's differences, the traces of its continuous multiplicity. Time "itself" is not just beyond the horizon of philosophical discourse, but always in the process of filtering across the junctureless boundary from metaphysics to science. This may be stretching a lot out of fractals, but then-for the nontechnical user-it is a lot more interesting to think about them as philosophical figures than it is to design them on a computer graphics program.

Here one perceives the crucial difference between utilizing diagrams as conceptual schemas that enable a speculative mapping between chaos theory and Bergson's metaphysics and a more literal semiotic that in essence collapses conscious experience onto or into the digital domain. This analysis of Bergson's duration in relation to chaos diagrams underscores an important connection between a mode of reading science and a philosophical premise implicit in Bergson's work which becomes more telling today. This connection lies in the link between, on the one hand, insisting on the materiality of the chaos diagrams and the irreducible semiotic dimension inherent in all domains of discourse, including "pure" mathematics, and on the other hand, insisting on the corporeality of duration. Duration cannot be downloaded into digital form, encoded as a software, simply because embodiment makes a qualitative difference. Part of Bergson's legacy for scholars today in fact may well rest in retracing the lines along which he thought the problem of qualitative difference, the difference in kind, and bringing this line of distinction to bear on the many types of issues raised in sites where distinctions between the organic and the technological, between life and information begin to become blurred. 